\title{
PENGALAMAN KEPALA RUANGAN DALAM MELAKUKAN SUPERVISI KEPERAWATAN DIRUANG RAWAT INAP RSI IBNU SINA PADANG
}

\author{
Asmiati $^{1}$., Ardenny ${ }^{2}$ \\ ardenny 2010@yahoo.co.id
}

\begin{abstract}
Abstrak
Supervisi keperawatan bagian dari fungsi pengarahan dalam fungsi manajemen keperawatan yang mempunyai peran penting dalam meningkatkan kualitas pelayanan rumah sakit. Penelitian ini menggunakan metode kualitatif dengan pendekatan fenomenologi. Sebanyak empat orang kepala ruangan berpartisipasi pada penelitian ini. Metode pengumpulan data dilakukan dengan cara wawancara mendalam dan field note. Hasil penelitian dilakukan analisis dengan metode colaizzi. Adapun tema-tema yang dihasilkan pada penelitian ini antara lain: 1) Persepsi kepala ruangan tentang supervisi, 2) Cara melakukan supervisi secara lansung, 3) Cara melakukan supervisi tidak lansung, 4) Hambatan dalam melakukan supervisi tidak lansung, 5) Dukungan yang diperlukan dari organisasi, dan 6) Harapan terhadap pelaksanaan supervisi. Kesimpulan penelitian didapatkan bahwa supervisi keperawatan belum begitu optimal dilakukan oleh kepala ruangan. Rumah sakit perlu mengembangkan program peningkatan pengetahuan kepala ruangan melalui pelatihan, seminar maupun desiminasi ilmu mengenai supervisi keperawatan yang diadakan oleh rumah sakit maupun diluar rumah sakit. Selain itu perlu adanya dukungan dari organisasi bagi kepala ruangan dalam melakukan supervisi keperawatan.
\end{abstract}

Kepustakaan : 23 (1999 - 2012)

Kata kunci : Supervisi, keperawatan, pengalaman

\begin{abstract}
Absract
Treatment supervision is part of guidance function in treatment management function having important role in improving the quality of service of hospital. This research use method qualitative with approach of fenomenologi. Four of people lead room participate this research. Method data collecting conducted by indepth interview and field notes. Result of research analyse with method of colaizzi. As for yielded themes at this research for example 1) Perception lead room about supervision 2) Way of supervise by lansung 3) Way of supervision do not lansung 4) Resistance in supervision do not lansung 5) needed support of organization, and 6) Expectation to execution of supervision. Conclusion of research got that treatment supervision not yet optimal so conducted by room head. Hospital require to develop program of is make-up of knowledge of room head through training, and also seminar of desiminasi science concerning treatment supervision
\end{abstract}


performed by hospital and also is outdoors of pain. Besides needing the existence of support of organization to room head in supervise treatment.

Reference : 23 (1999-2012)

Key Word : Nursing, Supervision, Experince

\section{PENDAHULUAN}

Upaya penyelenggaraan menjaga kualitas pelayanan kesehatan dirumah sakit tidak lepas dari peran penting dari seluruh profesi dirumah sakit. Perawat sebagai salah satu profesi dirumah sakit mempunyai peran sentral dalam upaya mencapai tujuan pelayanan kesehatan yang berkualitas pada pasien dan keluarga. Menurut Gillies (2000) dalam Suardi \& Bachtiar (2002), mengatakan bahwa hasil studi yang dilakukan dibeberapa rumah sakit, profesi keperawatan berjumlah $60 \%-70 \%$ dari keseluruhan tenaga kerja yang ada dirumah sakit. Supervisi yang baik dapat membantu dalam menjaga dan meningkatkan kualitas pelayanan keperawatan, hal ini dikarenakan supervisi merupakan suatu pengamatan atau pengawasan secara lansung terhadap pelaksanaan pekerjaan yang bersifat rutin (Arwani \& Supriyanto, 2005). Menurut Kron (1987) dalam Seeker (2009), perencanaan supervisi berisi tentang apa yang akan disupervisi, siapa yang akan disupervisi, bagaimana tekniknya, kapan waktunya dan alasan dilakukan supervisi. Setelah perencanaan dibuat maka langka selanjutnya supevisor harus dapat memberikan pengarahan pada stafnya. Supervisor mempunyai peranan penting dalam memotivasi staf untuk mencapai tujuan organisasi (Seeker, 2009).
Kemampuan supervisor dalam memberikan motivasi adalah untuk meningkatkan semangat kerja staf dalam pelaksana keperawatan (Arwani \& Supriyanto, 2005). Motivasi yang diberikan oleh supervisor dapat berupa perhatian yang diberikan pada staf dalam menyelesaikan pekerjaan, dengan adanya perhatian, staf dapat termotivasi sehingga timbul minat untuk menyelesaikan pekerjaan dengan baik. Tugas akhir dari supervisor dalam melakukan supervisi adalah melakukan evaluasi terhadap kegiatan supervisi. Evaluasi merupakan proses penilaian pencapaian tujuan. Apabila suatu pekerjaan sudah selesai dikerjakan oleh staf, maka diperlukan suatu evaluasi sebagai upaya pelaksanaan dan membandingkan dengan rencana yang telah disusun sebelumnya (Seeker, 2009). Evaluasi juga digunakan untuk menilai apakah pekerjaan tersebut sudah dikerjakan sesuai dengan ketentuan untuk mencapai tujuan organisasi. Evaluasi dapat dilakukan dengan cara menilai lansung kegiatan, memantau kegiatan melalui objek kegiatan. Apabila suatu kegiatan sudah di evaluasi, maka diperlukan umpan balik terhadap kegiatan tersebut (Nursalam, 2012).

Banyaknya manfaat yang didapat dari pelaksanaan supervisi, namun masih belum mampu menjadi pemicu dilaksanakannya supervisi dengan 
baik dan benar. Kepala ruangan sebagai supervisor keperawatan diruangan yang dipimpinnya terkadang tidak mampu menjalankan supervisi secara baik, hal ini dapat disebabkan strata pendidikan kepala ruangan yang belum merata dan pemahaman kepala ruangan tentang supervisi belum begitu baik. Menurut Arwani \& Supriyanto (2005), seorang manajer keperawatan agar mampu melaksanakan kegiatan supervisi secara benar, ia harus mengetahui dasar dan prinsipprinsip dari supervisi. Hambatan yang dialami kepada ruangan dalam melakukan supervisi sangat bervariasi, salah satunya adalah hambatan dari kompetensi yang dimiliki oleh kepala ruangan tentang pelaksanaan supervisi. Hasil penelitian Siswana (2008), tentang hubungan peran supervisi kepala ruangan dengan kinerja perawat pelaksana. Hasil penelitian menunjukkan bahwa ada hubungan bermakna antara peran supervisi kepala ruangan terhadap kinerja perawat pelaksana, hal ini berarti semakin tinggi peran supervisi kepala ruangan maka semakin tinggi hasil kinerja perawat pelaksana.

Studi pendahuluan yang dilakukan di ruang rawat inap Rumah Sakit Islam (RSI) Ibnu Sina Padang, tentang pelaksanaan supervisi keperawatan yang dilakukan para kepala ruangan, didapatkan $86,3 \%$ kepala ruangan mengalami berbagai macam hambatan, baik hambatan saat melakukan supervisi secara lansung maupun hambatan saat melakukan supervisi secara tidak lansung. Dari $86,3 \%$ hambatan yang dialami kepala ruangan dalam melakukan supervisi keperawatan, 48,1\% kepala ruangan mengalami hambatan dalam melakukan supervisi secara lansung dan $38,2 \%$ kepala ruangan mengalami hambatan dalam melakukan supervisi secara tidak lansung. Hasil wawancara yang dilakukan pada 4 orang kepala ruangan, didapatkan informasi bahwa 3 dari 4 orang kepala ruangan yang diwawancara mengalami hambatan dalam melakukan supervisi terutama dalam melakukan supervisi secara lansung pada staf keperawatan.

\section{Tujuan Penelitian}

Mengetahui pengalaman kepala ruangan dalam melakukan supervisi keperawatan diruang rawat inap RSI Ibnu Sina Padang.

\section{Jenis penelitian}

Jenis penelitian yang digunakan pada penelitian ini adalah kualitatif dengan pendekatan fenomenologi. Jenis penelitian kualitatif dengan pendekatan fenomenologi tepat untuk menggali secara mendalam tentang hambatan kepala ruangan dalam melakukan supervisi keperawatan di RSI Ibnu Sina Padang, baik hambatan yang dialami kepala ruangan dalam melakukan supervisi secara lansung maupun hambatan dalam melakukan supervisi secara tidak lansung.

\section{Populasi dan sampel}

Informan pada penelitian ini adalah kepala ruangan di ruang rawat inap RSI Ibnu Sina Padang sebanyak 4 orang.

\section{Tempat dan Waktu penelitian}

Tempat penelitian dilakukan RSI Ibnu Sina Padang dimulai dari bulan Maret sampai dengan Juni 2013.

\section{Alat penggumpulan data}

Pedoman wawancara dan lembar observasi 
Uji validitas dan reliabilitas

Validitas data diperlukan agar informasi yang diperoleh dalam penelitian valid. Valiadasi data dilakukan dengan cara mengecek atau memeriksa data yang telah didapat. Menurut Moleong (2010), terdapat empat kriteria yang digunakan yaitu kepercayaan (creadibility), ketergantungan (dependability), $\quad$ keteralihan (transferability) dan kepastian (confirmability).

\section{Analisa data}

Menggunakan metode Colaizzi. Menurut Pollit dan Beck (2004) dalam Sugiyono (2010), analisis data yang dilakukan dengan menggunakan metode Colaizzi.

\section{HASIL PENELITIAN}

Tabel 4.1

Karakteristik Informan di Ruang Rawat Inap RSI Ibnu Sina Padang

\begin{tabular}{cccccc}
\hline No. & $\begin{array}{c}\text { Inisial } \\
\text { Informan }\end{array}$ & Umur & $\begin{array}{c}\text { Jenis } \\
\text { Kelamin }\end{array}$ & Pendidikan & $\begin{array}{c}\text { Lama bekerja } \\
\text { sebagai karu }\end{array}$ \\
\hline 1 & P1 & 35 th & PR & D3 & $>2$ th \\
\hline 2 & P2 & 37 th & PR & D3 & $>3$ th \\
\hline 3 & P3 & 35 th & PR & D3 & $>3$ th \\
\hline 4 & P4 & 33 th & PR & D3 & $>5$ th \\
\hline
\end{tabular}

\section{Persepsi Kepala Ruangan terhadap Supervisi}

Persepsi merupakan pandangan terhadap sesuatu hal, sedangkan persepsi kepala ruangan terhadap supervisi keperawatan adalah pandangan kepala ruangan tentang supervisi keperawatan yang mereka lakukan terhadap perawat pelaksana. Sebagian informan mengatakan bahwa supervisi adalah melakukan bimbing dan motivasi terhadap perawat pelaksana, hal ini diketahui dari hasil wawancara mendalam yang dilakukan oleh peneliti kepada dua informan berikut ini :

"Motivasi yang saya berikan
ya...seperti untuk dapat
menyelesaikan pemberian asuhan
keperawatan dan
menyelesaikan pekerjaan, kalau
untuk bimbingan saya secara
lansung melihat pekerjaan perawat
dan melakukan bimbingan
bagaimana tindakan yang harus
dilakukan dengan benar dan
terkadang saya juga memberikan
contoh bagaimana tindakan
keperawatan yang sebenarnya" (Pl)
"Seperti memberikan motivasi untuk
menyelesaikan pekerjaan dengan
baik dan memberikan bimbingan bila
ada perawat yang melakukan
pekerjaan yang tidak sesuai dengan
SOP, disini saya mengajarkan


bagaimana tindakan yang sebenarnya" (P4).

2. Hambatan Kepala Ruangan dalam melakukan Supervisi.

Kepala ruangan dalam melakukan supervisi keperawatan, baik melakukan supervisi secara lansung maupun secara tidak lansung mengalami berbagai macam hambatan. Untuk hambatan yang sering dialami oleh kepala ruangan dalam melakukan supervisi secara lansung adalah waktu, hal ini disebabkan karena kepala ruangan tidak memiliki waktu yang cukup untuk dapat melakukan supervisi sebab kepala ruangan juga harus melakukan berbagai macam kegiatan atau tugas rangkap lainnya, dimana hal ini disampaikan oleh semua informan :

"Kalau hambatan mungkin banyak buk, tetapi saya rasa hambatan yang paling mendasar ya "waktu" karena waktu saya banyak terhabiskan dengan pekerjaan yang semestinya bukan pekerjaan saya, jadi supervisi yang semestinya sebagai tugas pokok saya sering terabaikan" (P1)

"Kayaknya yang paling mendasar waktu, karena itu tadi buk, pekerjaan saya kan rangkap, jadi waktu saya sedikit yang ada untuk melakukan supervisi, terkadang supervisinya molor-molor terus..." (P2)

"Pekerjaan saya yang banyak, saya kerja rangkap, jadi banyak menyita waktu sehingga untuk melakukan supervisi tidak terjadwal dengan baik" (P3)

"Seperti yang sudah saya katakan tadi, bahwa waktu saya banyak tersita oleh pekerjaan yang bukan mestinya saya yang mengerjakan, bila hal tersebut dapat diatasi saya rasa supervisi dapat terlaksana secara teratur" (P4)

3. Dukungan Organisasi terhadap Kepala Ruangan dalam Melakukan Supervisi

Organisasi merupakan suatu wadah yang menawungi beberapa orang didalamnya, begitupun dengan organisasi keperawatan yang bertujuan untuk menawungi, melindungi dan memberikan motivasi serta harapan kepada semua perawat. Kepala ruangan yang merupakan sebagai seorang supervisor keperawatan dalam sebuah ruang yang dikelolanya mempunyai tugas pokok untuk melakukan supervisi keperawatan terhadap stafnya. Dalam melakukan supervisi keperawatan hendaknya kepala ruangan harus mendapatkan dukungan dari organisasi, agar supervisi keperawatan yang dilakukan mendapat pengakuan dan diterima bagi staf yang disupervisi.

Menurut informan yang diwawancarai, dukungan dari organisasi sangat diperlukan terhadap pelaksanaan supervisi keperawatan, seperti dukungan dari atasan atau dari kepala bidang keperawatan. Hal ini disampaikan oleh informan berikut ini :

"Yang paling saya perlukan (tampak berpikir) dukungan dari atasan" (P1)

"Dukungan yang sangat diperlukan ya...dari atasan terutama dari bidang keperawatan" (P2)

"Saya sangat memerlukan dukungan dari kepala bidang keperawatan" (P3)

"Yang terpenting bagi saya adanya dukungan dari atasan” (P4) 
4. Harapan Kepala Ruangan Terhadap Pelaksanaan Supervisi Keperawatan

Harapan merupakan angan-angan bagi seseorang yang menginginkan harapannya menjadi kenyataan. Untuk harapan kepala ruangan terhadap pelaksanaan supervisi keperawatan adalah keinginan kepala ruangan agar apa yang diharapkannya terhadap pelaksanaan supervisi keperawatan menjadi kenyataan. Dari berbagai banyaknya hambatan yang dialami kepala ruangan dalam melakukan supervisi keperawatan, tentunya kepala rungan mempunyai harapan agar supervisi yang dilakukannya menjadi lebih baik, hal ini disampaikan oleh informan berikut ini :

"Harapan saya adanya penambahan jumlah tenaga sehingga pekerjaan yang ada dapat terselesaikan dengan baik, sehingga saya tidak mempunyai pekerjaan rangkap dan saya dapat melakukan supervisi dengan jadwal tertentu” (P1)

"Kayaknya penambahan jumlah tenaga, jadi tugas pokok masing masing dapat dilaksanakan sebagai mana mestinya, seperti saya kepala ruangan hanya melakukan tugas sebagai kepala ruangan tidak ikut melakukan pekerjaan perawat pelaksana"(P2)

"Adanya penambahan jumlah tenaga sehingga saya mempunyai waktu khusus untuk melakukan supervisi, selain itu saya juga berharap ada jadwal khusus untuk supervisi yang ditetapkan oleh bidang keperawatan"(P3).

"Harapan saya hendaknya adanya dukungan khusus dari atasan untuk pelaksanaan supervisi bagi kepala ruangan"(P4)

\section{Pembahasan}

1. Persepsi Kepala ruangan terhadap Supervisi

Hasil penelitian ini sama dengan definisi supervisi yang dikemukakan oleh Kron (1987) dalam Seeker (2009), dimana supervisi merupakan kegiatan mengarahkan, merencanakan, mengajarkan, mengobservasi, mendorong, memperbaiki, mempercayai dan mengevaluasi secara terus menerus pada setiap perawat dengan sabar, adil dan bijaksana sehingga setiap perawat dapat memberikan asuhan keperawatan dengan baik, terampil, aman, cepat dan tepat secara menyeluruh sesuai dengan kemampuan dan keterbatasan dari perawat. Sedangkan Suardi \& Bachtiar (2002), mengatakan bahwa supervisi adalah melakukan pengamatan secara lansung dan berkala oleh atasan terhadap pekerjaan yang dilakukan bawahan untuk kemudian bila ditemukan masalah segera diberikan bantuan yang bersifat lansung guna mengatasinya.

Kepala ruangan sebagai supervisor diruangan yang dipimpinnya mempunyai tugas untuk melakukan supervisi kepada stafnya dalam hal ini adalah perawat pelaksana. Menurut Kron (1987) dalam Nursalam (2012), peran kepala ruangan dalam melakukan supervisi adalah peran dalam membuat perencanaa, memberikan pengarahan, melakukan bimbingan, memberikan motivasi, melakukan observasi dan juga melakukan evaluasi terhadap kinerja perawat pelaksana, dimana sumua ini merupakan satu kesatuan yang harus dilakukan oleh kepala ruangan dalam 
melakukan supervisi. Bila ada salah satu atau beberapa hal dari satu kesatuan yang menjadi kegiatan supervisi tidak dilakukan oleh kepala ruangan maka supervisi tersebut bisa tidak menjadi maksimal.

Hasil catatan lapangan (field notes) memperlihatkan bahwa kepala ruangan kurang mampu mempersepsikan supervisi keperawatan dengan baik, hal ini terlihat disaat kepala ruangan sulit mengungkapkan pengertian dan cara pelaksanaan dari supervisi keperawatan. Selain itu kepala ruangan juga terlihat jarang melakukan supervisi keperawatan, terutama dalam melaksanakan supervisi secara tidak lansung. Terkendalanya kepala ruangan dalam melakukan supervisi secara tidak lansung, hal ini disebabkan oleh karena pendokumentasian yang tidak lengkap dan banyaknya pekerjaan yang harus dilakukan oleh kepala ruangan.

\section{Hambatan Kepala Ruangan dalam Melakukan Supervisi}

Berdasarkan informasi yang diperoleh dari hasil wawancara mendalam dengan informan mengenai hambatan-hambatan kepala ruangan dalam melakukan supervisi. Didapatkan informasi bahwa semua informan mengalami hambatan dalam melakukan supervisi keperawatan. Dimana hambatan yang paling sering dialami kepala ruangan adalah ketika melakukan supervisi secara tidak lansung, hal ini disebabkan karena ketersedian waktu yang kurang bagi kepala ruangan untuk dapat melakukan supervisi keperawatan. Kepala ruangan yang merupakan seorang supervisor keperawatan, belum mampu melakukan supervisi dengan baik, hal ini dikarenakan kepala ruangan masih banyak mengalami berbagai macam hambatan dalam melakukan supervisi, terutama hambatan dari ketersediaan waktu. Ketersediaan waktu yang sedikit untuk melakukan supervisi juga disebabkan oleh beberapa keadaan seperti kepala ruangan yang masih melakukan pekerjaan rangkap. Kepala ruangan yang masih melakukan pekerjaan rangkap juga disebabkan karena jumlah tenaga keperawatan yang masih kurang, dimana keadaan ini membuat kepala ruangan masih harus ikut serta untuk menyelesaikan pekerjaan dari perawat pelaksana. Penyebab hambatan yang dialami kepala ruangan untuk melakukan supervisi salah satunya juga disebabkan oleh jumlah tenaga keperawatan yang belum optimal.

Hasil catatan lapangan (field notes) memperlihatkan bahwa kepala ruangan dalam melakukan supervisi keperawatan selalu mengalami berbagai macam hambatan, hal ini terlihat dengan tidak teraturnya supervisi yang dilakukan. Penyebab kurang teraturnya supervise yang dilakukan oleh kepala ruangan,hal ini dikarenakan terlalu banyaknya pekerjaan yang harus dilakukan oleh kepala ruangan, termasuk melakukan pekerjaan perawat pelaksana.

\section{Dukungan dari Organisasi terhadap Kepala Ruangan dalam Melakukan Supervisi}

Berdasarkan informasi yang diperoleh dari hasil wawancara mendalam dengan semua informan mengenai dukungan dari organisasi terhadap kepala ruangan dalam melakukan supervisi. Didapat informasi bahwa kepala ruangan 
memerlukan dukungan dari organisasi dalam melakukan supervisi keperawatan, dukungan tersebut terutama diperlukan dari atasan atau dari kepala bidang keperawatan. Namun sampai saai ini kepala ruangan belum mendapatkan dukungan tersebut, hal ini membuat informan berpendapat bila tidak ada dukungan dari organisasi maka supervisi keperawatan tidak akan berjalan dengan baik atau optimal, ini disebabkan kerena supervisi yang mereka lakukan tidak ada yang menilai atau tidak adanya anjuran berupa surat keputusan yang mewajibkan kepala ruangan untuk melakukan supervisi sehingga informan beranggapan bahwa supervisi keperawatan merupakan kegiatan yang tidak wajib. Keadaan ini yang membuat informan berpendapat bahwa supervisi tidak akan berjalan dengan baik atau optimal. Belum adanya dukungan sampai saat ini dari organisasi terutama dari atasan atau bidang keperawatan terhadap pelaksanaan supervisi keperawatan oleh kepala ruangan, hal ini disebabkan oleh karena masih kurangnya pemahaman organisasi terhadap pelaksanaan supervisi keperawatan, ini dibuktikan dengan kurangnya pelaksanaan pelatihan, desiminasi ilmu dan seminar tentang supervisi yang diadakan oleh organisasi. Selain itu organisasi juga belum merasakan manfaat dari pelaksanaan supervisi keperawatan bagi organisasi, ini disebabkan karena supervisi yang dilakukan oleh kepala ruangan belum begitu baik dan optimal. Beberapa keadaan tersebut membuat organisasi belum memberikan dukungan penuh terhadap pelaksanaan supervisi keperawatan.

\section{Harapan Kepala Ruangan terhadap Pelaksanaan Supervisi Keperawatan}

Berdasarkan informasi yang diperoleh dari hasil wawancara mendalam dengan semua informan mengenai harapan kepala ruangan terhadap pelaksanaan supervisi keperawatan. Didapatkan informasi bahwa informan mempunyai harapan yang besar terhadap pelaksanaan supervisi keperawatan untuk menjadi lebih baik dan optimal. Harapan tersebut adanya penambahan jumlah tenaga keperawatan sehingga dengan adanya penambahan jumlah tenaga keperawatan, kepala ruangan tidak lagi melakukan pekerjaan rangkap dan perawat pelaksana juga mempunyai waktu yang cukup untuk melakukan pendokumentasian secara lengkap. Adanya harapan informan terhadap penambahan jumlah tenaga keperawatan, diharapkan agar kepala ruangan tidak lagi mempunyai pekerjaan rangkap sehingga kepala ruangan hanya melakukan tugas pokoknya sebagai kepala ruangan termasuk didalamnya tugas untuk melakukan supervisi keperawatan. Dengan adanya waktu yang cukup, maka kepala ruangan akan dapat melakukan supervisi dengan terjadwal. Bagi perawat pelaksana dengan adanya penambahan jumlah tenaga keperawatan, maka pekerjaan perawat pelaksana akan berkurang atau menjadi ringan, hal ini akan membuat perawat pelaksana mempunyai waktu yang cukup untuk mendokumentasikan tindakan yang dilakukan kepada pasien. Pendokumentasian yang lengkap akan mempermudah kepala ruangan untuk melakukan supervisi keperawatan secara tidak lansung. Selain itu, dengan dokumentasian 
yang lengkap maka perawat pelaksana bisa mempertahankan aspek legal nya bila terjadi suatu dugaan kasus mal praktek yang dilakukan oleh perawat.

\section{Keterbatasan Penelitian}

Ada beberapa faktor yang mempengaruhi penelitian ini seperti situasi, kondisi dan lingkungan pada saat peneliti melakukan wawancara. Hal ini menjadi salah satu keterbatasan penelitian ini untuk memperoleh data yang sempurna. Keadaan ini sangat berpengaruh terhadap informasi yang diberikan oleh partisipan yang hanya berdasarkan daya ingat dan perasaan partisipan pada saat wawancara, jadi mungkin saja terjadi faktor kelupaan bagi partisipan.

\section{Saran}

1. Melakukan upaya peningkatan pengetahuan kepala ruangan dengan cara memprogramkan kepala ruangan untuk mengikuti seminar, pelatihan maupun diseminasi ilmu yang diadakan oleh rumah sakit maupun luar rumah sakit yang terkait dengan supervisi keperawatan.

2. Melakukan penambahan jumlah tenaga keperawatan yang sesuai dengan kebutuhan rumah sakit dalam upaya mengatasi hambatan kepala ruangan dalam melakukan supervisi keperawatan.

\section{Daftar Pustaka}

Amalia, E, (2012). Hubungan supervisi kepala ruangan dengan kinerja perawat pelaksana dalam melaksanakan tindakan keperawatan di RSUD Dr. Achmad Mochtar Bukit Tinggi. Tesis. Pasca Sarjana Keperawatan Universitas Andalas Padang, tidak dipublikasikan.

Anna, M \& Taylor, R.N. (2005). Supervision In Nursing. (http://ncbi.mlm.nic.gov/pub med/1509780, diakses $21 \mathrm{Juli}$ 2013).

Arwani \& Suprianto, (2005). Manajemen bangsal keperawatan. Jakarta: EGC

Azwar, S, (2009). Sikap manusia: Teori dan pengukuran. Yogyakarta: Pustaka Pelajar.

Butterworth, C.A. (2004). Clinical supervision in nursing, midwifery and health visiting. (http://nursing.nic.pubmed.90 $87650234 /$ gov/org=0986750, diakses 21 Juli 2013)

Carpenito, L.J. (1999). Nursing care plans and documentation. Philadelphia: JB Lippincott

Depkes RI, (1999). Sistem kesehatan nasional. Jakarta: Depkes RI.

Depkes RI. (2001). Petunjuk pelaksanaan indikator mutu pelayanan Rumah Sakit.

Depkes RI (2007). Pedoman nasional etika penelitian kesehatan. Jakarta: Kominsi Nasional Etika Peelitian Kesehatan.

Procter. B (2011). On being a trainer and supervision for counselling in action. (http//www.nursingboard/pub 
med/gov.id $=09876777000567$

=govic, diakses 22 Juli 2013)

Ridha, R, (2012) Hubungan persepsi kepala ruangan tentang supervisi dengan pelaksanaan supervisi keperawatan di instalasi rawat inap RSUP Dr. M.Djamil Padang. Tesis. Pasca Sarjana Keperawatan Universitas Andalas Padang, tidak dipublikasikan.

Seeker, (2009). Manajemen supervisi. Jakarta: Rajawali Pers.

Siagian, S. (2004). Manajemen sumber daya manusia. Jakarta: Bumi Aksara.

Siswana, L. (2008). Hubungan peran supervisi kepala ruangan dengan kinerja perawat pelaksana di RSUD Petala Bumi. Tesis. Depok: UI. Tidak dipublikasikan.

Suardi \& Bachtiar. (2002). Manajemen keperawatan dengan pendekatan praktis. Jakarta: Penerbit Erlangga.

Sugiyono, (2010). Memahami penelitian kualitatif. Bandung: Alfabeta.

Sukardjo, (2010). Supervisi dalam manajemen keperawatan. (http;//www.example.com, diakses 4 Maret 2013).

Sumijatun, (2010). Konsep dasar menuju keperawatan profesional. Jakarta: Trans Info Media.
Swansburg, R. (1999). Pengantar kepemimpinan dan manajemen keperawatan untuk Perawat Klinis. Jakarta: EGC.

Uhar, S. (2013). Penelitian kualitatif, (http;//www.Pdpersi.co.id, diakses 10 Maret 2013).

Tim Pascasarjana Unand. (2012). Pedoman penulisan Tesis. Padang: tidak dipublikasikan

Wardana, C.F. (2012). Kiat sukses mensupervisi medical reps. Yogyakarta: Aswaja Pressindo.

Widiawati, S, (2012). Hubungan sistem dan pelaksanaan supervisi dengan motivasi perawat pelaksana dalam pendokumentasian asuhan keperawatan di RSUD Dr. Achmad Mochtar Bukit Tinggi. Tesis. Pasca Sarjana Keperawatan Universitas Andalas Padang, tidak dipublikasikan. 